\title{
Induction of Human Squamous Cell-Type Carcinomas by Arsenic
}

\author{
Victor D. Martinez, Daiana D. Becker-Santos, Emily A. Vucic, \\ Stephen Lam, and Wan L. Lam \\ Department of Integrative Oncology, BC Cancer Research Centre, 675 West 10th Avenue, Vancouver, BC, Canada V5Z 1L3 \\ Correspondence should be addressed to Victor D. Martinez, vmartinez@bccrc.ca
}

Received 2 August 2011; Accepted 7 October 2011

Academic Editor: Daniela Massi

Copyright ( 2011 Victor D. Martinez et al. This is an open access article distributed under the Creative Commons Attribution License, which permits unrestricted use, distribution, and reproduction in any medium, provided the original work is properly cited.

\begin{abstract}
Arsenic is a potent human carcinogen. Around one hundred million people worldwide have potentially been exposed to this metalloid at concentrations considered unsafe. Exposure occurs generally through drinking water from natural geological sources, making it difficult to control this contamination. Arsenic biotransformation is suspected to have a role in arsenic-related health effects ranging from acute toxicities to development of malignancies associated with chronic exposure. It has been demonstrated that arsenic exhibits preference for induction of squamous cell carcinomas in the human, especially skin and lung cancer. Interestingly, keratins emerge as a relevant factor in this arsenic-related squamous cell-type preference. Additionally, both genomic and epigenomic alterations have been associated with arsenic-driven neoplastic process. Some of these aberrations, as well as changes in other factors such as keratins, could explain the association between arsenic and squamous cell carcinomas in humans.
\end{abstract}

\section{Background}

Arsenic is a well-known human carcinogen (Class I, according to the International Agency for Research on CancerIARC [1]). Recommended thresholds for arsenic concentration in drinking water is $\leq 10 \mu \mathrm{g} / \mathrm{L}[2,3]$ however, chronic exposure exceeding this limit has been reported worldwide affecting nearly one hundred million people worldwide daily, especially in Bangladesh, Taiwan, Mongolia, India, China, Argentina, Mexico, Canada, USA, and Chile, among others countries [4-9]. Long-term effects are a major health concern in affected areas.

In the environment, arsenic can be found with an oxidation state +3 (known as arsenite or As [III]), or +5 (arsenate or As [V]), exhibiting different grades of toxicity [10]. Increased levels of inorganic arsenic (combined with oxygen, chlorine, and sulfur, among other elements) in drinking water is the major cause of arsenic toxicity $[11,12]$.

Both neoplastic and nonneoplastic effects have been described as consequence of arsenic exposure. Nonneoplastic effects primarily include peripheral vascular disorders (e.g., "black foot disease" almost exclusively observed in zones of Taiwan affected by arsenic contamination [13]), hypertension, diabetes, severe atherosclerosis, neuropathies, and, importantly, skin alterations, such as hyperkeratosis and hyperpigmentation [13-16]. Hyperkeratosis is particularly relevant, because it has been described as a precursor lesion of skin cancer tumors associated with arsenic exposure [1719].

Several types of cancer have been attributed to arsenic exposure [20-25]. Skin, bladder, and lungs are the major target organs affected by different routes of exposure. Skin cancer is the most common form of malignant tumor related to arsenic ingestion. Lung cancer is the most deadly form of cancer associated to arsenic exposure [26, 27]. For internal organs, bladder cancer exhibits the highest relative risk [20, $28,29]$. Other less common types of cancer associated with arsenic exposure include kidney, liver, and prostate cancers $[30,31]$.

The mechanism of arsenic-induced diseases remains to be elucidated. When arsenic enters the human body, it is readily reduced from the pentavalent arsenical species to trivalent forms, and, subsequently, there are a series of oxidative methylation reactions leading to the generation of tri- and pentavalent methylated metabolites [32]. It has been proposed that the biotransformation processes of arsenic activate its carcinogenic potential. This hypothesis was supported by the observation that the methylated arsenical 
species (specially trivalents) exhibit aberrant effects such as enzyme inhibition (particularly oxidoreductases), damage to DNA structure, and activation AP-1-dependent gene transcription $[33,34]$.

Neoplastic effects as a result of arsenic biotransformation can occur at the genetic and epigenetic levels. Arsenic can damage DNA, mostly through oxidative stress by generation of toxic species such as reactive oxygen species (ROS), which can potentially lead to genomic aberrations.

Figure 1 Secondly, arsenic uses S-adenosylmethionine (SAM) as a methyl group donor during its biotransformation. As a consequence, deprivation of the cellular pool of methyl groups can block certain cellular processes, resulting in alteration of epigenetic mechanisms that can contribute to arsenic-induced carcinogenesis [35]. Arsenic and arsenic metabolites can directly and indirectly affect normal epigenetic transcriptional regulation at the level of DNA methylation, histone maintenance, and miRNA expression (Figure 1) [36, 37].

1.1. Cell-Type Specificity on Arsenic-Induced Cancers. Despite physiological differences among target organs for arsenic carcinogenicity, a common characteristic has been described, namely, a squamous cell-type preference, independent of the affected organ. In fact, SqCC is one of the most common cancers seen in chronic-arsenic-exposed humans [38, 39]. Cell-type specificity has been previously described mainly for skin and lung cancer, and some studies have shown associations with liver cancer $[40,41]$. In this paper, we will focus on specificity reported in two main arsenic-associated types of cancer, namely, skin and lung cancers.

1.2. Skin Cancer and Arsenic Exposure. Skin cancer is the most common malignancy associated with arsenic ingestion through drinking water [26]. There are three major pathological cell types of skin cancer: basal cell carcinoma (BCC), squamous cell carcinoma (SqCC), and malignant melanoma. The first two cell types are the most common types of skin cancer, and they belong to the group of nonmelanoma skin cancers. Exposure to arsenic in drinking water has been associated with the incidence of SqCC and BCC, but not with the incidence of malignant melanoma [42]. Arsenic-related SqCC of the skin can develop either de novo or progress from Bowen's disease (BD), a premalignant skin disorder, frequently reported as a consequence of chronic arsenic exposure [43-46]. Additionally, there are differences between skin cancer cases induced and not induced by arsenic. For example, arsenic-related BCC develops typically in non-sunexposed areas of the body (contrary to UV-related skin cancer) and exhibits multiple foci [47].

Cell type specificity has been directly observed in chronically exposed human populations. In a key study from Taiwan, SqCC and BCC appear to be associated with ingestion of arsenic [42]. However, prior to skin cancer, the first observed effects of chronic arsenic exposure were nonmalignant skin lesions, such as hyperpigmentation and hyperkeratosis [43, 48]. Skin hyperkeratosis is common in chronic arsenicosis and is considered a precursor of SqCC because cancer can arise from these lesions [17-19].
Arsenic tends to concentrate in ectodermal tissue including the skin, hair, and nails [48]. Dermal absorption of arsenic is not the main exposure route, since some derivates of arsenic metabolism have low permeability $[49,50]$; however, both arsenite and arsenate accumulate in the dermis and epidermis [49]. In this context, epidermal stem cells have been proposed as a potential target for arsenicinduced carcinogenesis, since this metalloid can increase the relative proportion of stem cells in culture $[51,52]$.

Keratinocyte stem cells (KSCs) are a group of relatively quiescent cells with a broad proliferative potential and an unlimited capacity for self-renewal $[53,54]$. DSS1 (deleted in split hand/split foot 1) is a 12-O-tetradecanoyl phorbol-13acetate-(TPA-) inducible gene expressed in KSCs that plays an important role in skin carcinogenesis and is required for epidermal cell proliferation and oncogenic transformation [55]. DSS1 expression was significantly increased in SqCC induced in adult skin of Tg.AC mice-a strain sensitive to skin carcinogenesis via activation of the v-Ha-ras transgene likely in KSCs-by arsenic plus TPA compared with TPA alone [56]. Other genes responding to the same activation mechanisms in skin cancer, such Sprr2a, Ptges, and Colla2, were also increased in SqCC developed in Tg.AC mice $[56,57]$. Arsenic also has the potential to induce malignant transformation of human keratinocytes. Immortalized human epithelial cell line (HaCaT) exposed to $100 \mathrm{nM}$ of arsenic over 28 weeks generated highly aggressive SqCC when inoculated into nude mice [58].

Matrix metalloproteinase 9 (MMP-9) plays an important role in tumor progression, specifically in metastatic capacity, and its constitutive secretion correlates with the degree of tumorigenicity in human keratinocytes $[59,60]$. Human keratinocytes transformed by arsenic exhibit an increased secretion of MMP-9, to a similar degree observed in SqCC generated after inoculation of arsenic-transformed cells in mice [58]. This indicates that an aberrant expression of MMP-9 could be an early marker for arsenic-induced skin SqCC.

Finally, it has been suggested that arsenic can act as a skin cocarcinogen (Figure 1). In this context, it has been demonstrated that low concentrations of arsenic can increase tumor induction by UV-light in mice, with a high proportion of SqCC [61].

1.3. Lung Cancer and Arsenic Exposure. Lung cancer is the most deadly form of cancer associated to arsenic ingestion [27]. Several reports have shown a higher incidence of lung SqCC in populations exposed to arsenic (Table 1). This relationship has been demonstrated in several human populations. In Taiwan, patients from an endemic area of arsenic intoxication with exposures through drinking water had higher proportions of squamous cell and small cell carcinomas, but a lower proportion of adenocarcinomas [40].

In northern Chile, a high proportion of SqCC frequently occurs in never smokers who have been chronically exposed to arsenic, which is interesting, since SqCC is very frequently associated with cigarette smoking and its incidence has decreased worldwide [24, 62]. In rural areas of Bangladesh, arsenic contamination in drinking water from tube wells is associated with lung cancer in males, with lung SqCC being 


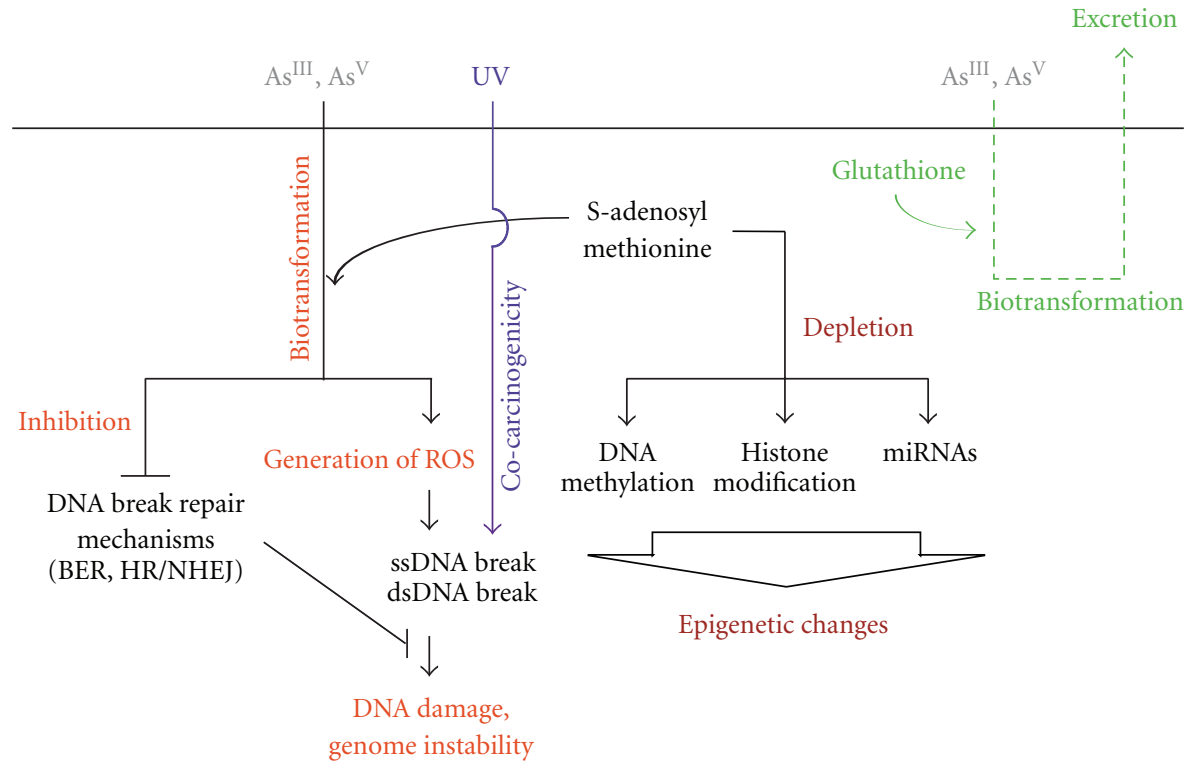

FIGURE 1: Carcinogenic mechanisms of arsenic transformation. Ingested arsenic undergoes a biotransformation process. (1) Biotransformation could lead to arsenic excretion, when conjugated with glutathione. (2) Biotransformation generates reactive oxygen species (ROS), namely, superoxide anions $\left(\mathrm{O}_{2}^{-}\right)$, hydrogen peroxide $\left(\mathrm{H}_{2} \mathrm{O}_{2}\right)$, hydroxyl radicals $(\mathrm{OH})$, that induce single-strand (ssDNA) and doublestrand (dsDNA) breaks by inducing oxidative damage. The process can also inhibit DNA break repair mechanisms for ssDNA breaks (base excision repair (BER)) and for dsDNA breaks (homologous recombination (HR) and/or nonhomologous end joining (NHEJ)). Additionally, ROS derived from arsenic biotransformation can act as cocarcinogens, for example, increasing damage potential of ultraviolet (UV) light. Furthermore, the requirement of S-adenosyl methionine (SAM) for arsenic biotransformation can lead to depletion of SAM, which is the substrate for DNA methylation.

the predominant histological subtype in areas with arsenic concentrations above $100 \mu \mathrm{g} / \mathrm{L}$ [63]. Additionally, lung SqCC was much more frequent among Bangladesh inhabitants who smoke and are exposed to arsenic in drinking water (concentrations $>100 \mathrm{mg} / \mathrm{L}$ ) compared to nonsmokers [63].

Studies in people occupationally exposed to arsenic have also revealed cell type specificity for arsenic-induced lung cancer. A postmortem study found that $37.6 \%$ of lung cancers among wine growers affected by chronic arsenic poisoning were of the SqCC type, a proportion significantly higher compared with three of the four reference populations [64]. On the other hand, smelter workers exposed to arsenic did not exhibit major changes in histological distribution for lung cancer (compared with reference group); however, lung SqCC has the highest number of cases, even among never smokers $[65,66]$. Conversely, other studies have shown no differences in histological types of lung cancer associated with arsenic exposure, challenging the hypothesis that small cell undifferentiated and epidermoid (SqCC) carcinomas are the only subtypes that increase in response to arsenic, among other carcinogens [67].

Information from German uranium miners who died from lung cancer during 1957-1990 was analyzed under the hypothesis that arsenic may influence the distribution of lung cancer types [68]. There was an arsenic-related increase in the proportion of lung SqCC among miners without silicosis at all levels of coexposure to radon and quartz dust.

1.4. Role of Keratins in Arsenic-Induced SqCC. The main structural proteins of the intermediate filament-based cytoskeleton of epithelial cells are the keratins [69]. Keratins are closely related with tissue-specific and cell-specific differentiation of epithelial cells [70], accordingly their roles in arsenic-induced SqCC have been explored. Interestingly, arsenic-induced carcinogenesis is related to enhanced expression of these cytoskeletal proteins in skin, liver, and bladder $[41,58,71-73]$.

Hyperkeratinization of stratified epithelia is a common clinical manifestation of arsenic exposure [17]. Notably, arsenic-associated SqCC typically arises from arsenicinduced hyperkeratotic lesions, suggesting that dysfunctional keratinization may play a critical role in arsenic-induced carcinogenesis [18]. In human keratinocytes, arsenic has been shown to promote a dramatic increase in expression of CK1, CK10, involucrin, and loricrin [58], which are major markers of squamous differentiation [74]. The epidermal stem cell markers CK5, CK14, and CK15 have also been shown to increase with arsenic exposure [72, 75-77]. CK8, CK17, and CK18 which are overexpressed in invasive SqCC, are also induced in arsenic-treated keratinocytes [72]. In addition to cell model studies, a population-based report of chronic arsenic exposure in Taiwan revealed progressive alterations in keratin expression in various skin lesions, including hyperkeratosis and SqCC. In this study, CK6, CK16, and CK17 were associated with arsenic exposure in SqCC [73].

The disruption in keratins induced by arsenic promotes the formation of DNA-protein cross-links, which can impair DNA replication [41]. The fact that arsenic has a high affinity to thiol groups, including those attached to thiol-rich proteins such as keratins, might contribute 
TABLE 1: Studies exhibiting associations between arsenic exposition and cell types of lung cancer.

\begin{tabular}{|c|c|c|c|c|c|c|}
\hline Location & $\begin{array}{l}\text { Number of lung } \\
\text { cancer cases }\end{array}$ & Cell type & Smoking status & Calculated risk & Dosage & Reference \\
\hline Britain & $\begin{array}{l}6 \text { cases treated } \\
\text { with Fowler's } \\
\text { solution or } \\
\text { potassium } \\
\text { arsenite ( } 2 \text { male } / 4 \\
\text { female) }\end{array}$ & $\begin{array}{l}\text { (i) } 5 \\
\text { undifferentiated } \\
\text { carcinomas } \\
\text { (ii) } 1 \mathrm{SqCC}\end{array}$ & $\begin{array}{l}3 \text { never smokers, } \\
1 \text { smoker }\end{array}$ & NA & NA & {$[94]$} \\
\hline Taiwan & $\begin{array}{l}\text { (i) } 76 \text { LC cases } \\
\text { (50 males/36 } \\
\text { females) } \\
\text { (ii) } 400 \text { controls } \\
\text { from the same } \\
\text { administrative } \\
\text { area }\end{array}$ & $\begin{array}{l}\text { (i) Male cases: } 40 \% \\
\text { SqCC, } 38 \% \text { AdC, } \\
22 \% \text { others } \\
\text { (ii) Female cases: } \\
19 \% \text { SqCC, } 69 \% \\
\text { AdC, } 11 \% \text { others }\end{array}$ & NA & $\begin{array}{l}\text { Odds ratios for developing LC } \\
\text { were } 3.39 \text { for whom used well } \\
\text { water from arsenic-contaminated } \\
\text { zones during } 40 \text { or more years, } \\
\text { compared with people who never } \\
\text { used such water source }\end{array}$ & $\begin{array}{l}\text { Median of } \\
780 \mu \mathrm{g} / \mathrm{L} \text { (artesian } \\
\text { wells) and } 40 \mu \mathrm{g} / \mathrm{L} \\
\text { (in well water) }\end{array}$ & {$[95]$} \\
\hline $\begin{array}{l}\text { Japan: Niigata } \\
\text { Prefecture }\end{array}$ & $\begin{array}{l}\text { (i) } 443 \\
\text { individuals } \\
\text { exposed to } \\
\text { arsenic } \\
\text { (ii) } 9 \text { ( } 8 \\
\text { male/1female) } \\
\text { developed lung } \\
\text { cancer after } \\
\text { exposure to high } \\
\text { levels } \\
(\geq 1000 \mu \mathrm{g} / \mathrm{L})\end{array}$ & $\begin{array}{l}\text { (i) } 3 \mathrm{SCC} \\
\text { (ii) } 2 \mathrm{SqCC} \\
\text { (iii) } 1 \mathrm{SqCC}+\mathrm{SCC}\end{array}$ & $\begin{array}{l}\text { All smokers, } \\
\text { except for female } \\
\text { case }\end{array}$ & $\begin{array}{l}\text { SMR }=15.6 \text { for developing LC } \\
\text { among individuals }(N=113) \\
\text { exposed to }>1000 \mu \mathrm{g} / \mathrm{L} \text { of arsenic } \\
\text { in drinking water in a zone } \\
\text { contaminated during } 5 \text { years in } \\
\text { Japan, while individuals exposed } \\
\text { to } 50-990 \mu \mathrm{g} / \mathrm{L}(N=76) \text { present a } \\
\text { SMR of } 2.33\end{array}$ & & {$[96]$} \\
\hline $\begin{array}{l}\text { Southwest } \\
\text { and } \\
\text { northeast } \\
\text { Taiwan }\end{array}$ & $\begin{array}{l}139 \text { newly } \\
\text { diagnosed LC } \\
\text { cases from a BFD } \\
\text { endemic zone }\end{array}$ & $\begin{array}{l}\text { (i) } 45 \% \text { SqCC } \\
\text { (ii) } 22 \% \mathrm{AdC}\end{array}$ & $\begin{array}{l}\text { (i) } 31.9 \% \text { never } \\
\text { smokers } \\
\text { (ii) } 16.7 \% \text { past } \\
\text { smokers } \\
\text { (iii) } 51.4 \% \\
\text { current smokers }\end{array}$ & $\begin{array}{l}\text { Relative risk according to exposure } \\
\text { group } \\
\text { (i) Group 1: } 1 \\
\text { (ii) Group 2: } 1.09 \\
\text { (iii) Group 3: } 2.28 \\
\text { (iv) Group 4: } 3.03 \\
\text { (v) Group 5: } 3.29\end{array}$ & $\begin{array}{l}\text { Average arsenic } \\
\text { level in } \\
\text { groundwater } \\
\text { ( } \mu \text { g/L) } \\
\text { (i) Group 1: <10 } \\
\text { (ii) Group 2: } \\
\text { 10-991 } \\
\text { (iii) Group 3: } \\
\text { 100-2991 } \\
\text { (iv) Group 4: } \\
\text { 300-699 } \\
\text { (v) Group } \\
\text { 5: } \geq 700\end{array}$ & {$[97]$} \\
\hline Taiwan & $\begin{array}{l}\text { National Cancer } \\
\text { Registration } \\
\text { Program with } \\
37.290 \text { LC } \\
\text { patients }(26.850 \\
\text { men/10.440 } \\
\text { women }\end{array}$ & $\begin{array}{l}\text { Men }^{\dagger} \\
\text { (i) } 33.6 \% \text { SqCC } \\
\text { (ii) } 19.5 \% \text { AdC } \\
\text { Women }{ }^{\dagger} \\
\text { (i) } 29.9 \% \text { SqCC } \\
\text { (ii) } 29.6 \% \text { SqCC }\end{array}$ & NA & $\begin{array}{l}\text { Male and female patients from } \\
\text { the BFD area had higher } \\
\text { proportions of SqCC } \\
(\mathrm{RR}=1.1 \text { in men and } \mathrm{RR}=1.9 \\
\text { in women }) \text { and } \mathrm{SCC}(\mathrm{RR}=1.2, \\
\text { in men, and } \mathrm{RR}=2.3 \text {, in } \\
\text { women) but had a lower } \\
\text { proportion of AdC } \\
(\mathrm{RR}=0.7 \text { in men and } \\
\mathrm{RR}=0.6 \text { in women) }\end{array}$ & $\begin{array}{l}\text { (i) Towns in BFD } \\
\text { area: average } \\
\text { arsenic level of } \\
0.22 \mathrm{mg} / \mathrm{L} \text { in well } \\
\text { water } \\
\text { (ii) Control } \\
\text { towns: } \\
\text { average arsenic } \\
\text { level of } 0.02 \mathrm{mg} / \mathrm{L}\end{array}$ & {$[40]$} \\
\hline Bangladesh & $\begin{array}{l}\text { (i) } 3.223(2811 \\
\text { male) with } \\
\text { a primary LC } \\
\text { (ii) } 1588(1183 \\
\text { male) with } \\
\text { benign lesions }\end{array}$ & $\begin{array}{l}50.5 \% \text { and } 39.0 \% \\
\text { of SqCC among } \\
\text { smokers and } \\
\text { nonsmokers, } \\
\text { respectively }\end{array}$ & $\begin{array}{l}\text { (i) } 79.7 \% \\
\text { smokers } \\
\text { (ii) } 18.5 \% \text { never } \\
\text { (iii) } 1.80 \% \\
\text { unknown }\end{array}$ & $\begin{array}{l}\mathrm{OR}=1.45 \\
(95 \% \text { CI } 1.16-1.80)\end{array}$ & $>100 \mu \mathrm{g} / \mathrm{L}$ & {$[63]$} \\
\hline
\end{tabular}


TABLE 1: Continued.

\begin{tabular}{|c|c|c|c|c|c|c|}
\hline Location & $\begin{array}{l}\text { Number of lung } \\
\text { cancer cases }\end{array}$ & Cell type & Smoking status & Calculated risk & Dosage & Reference \\
\hline $\begin{array}{l}\text { Northeastern } \\
\text { Taiwan }\end{array}$ & $\begin{array}{l}\text { (i) } 8086 \text { residents } \\
\text { were followed for } \\
11 \text { years ( } 6888 \\
\text { remained in the } \\
\text { final analysis) } \\
\text { (ii) } 178 \text { incident } \\
\text { LC cases }\end{array}$ & $\begin{array}{l}\text { (i) } 75(42.1 \%) \\
\text { SqCC } \\
\text { (ii) } 51(28.7 \%) \\
\text { AdC } \\
\text { (iii) } 22(12.4 \%) \\
\text { SCC }\end{array}$ & $\begin{array}{l}\text { At enrollment } \\
\text { (i) } 59.0 \% \text { never } \\
\text { smokers } \\
\text { (ii) } 12.4 \% \text { past } \\
\text { (iii) } 28.6 \% \\
\text { current }\end{array}$ & $\begin{array}{l}\text { The RRs and } 95 \% \text { CIs for } 100-300 \\
\text { and }>300 \mu \text { garsenic/L when } \\
\text { compared with }<10 \mu \mathrm{g} \text { arsenic/L } \\
\text { were } 1.54(0.97-2.46) \text { and } 2.25 \\
(1.43-3.55) \text {, respectively }\end{array}$ & $\begin{array}{l}\text { The mean } \\
\text { (arsenic) among } \\
\text { wells with known } \\
\text { arsenic } \\
\text { concentration } \\
\text { was } 117.2 \mu \mathrm{g} / \mathrm{L}\end{array}$ & {$[98]$} \\
\hline $\begin{array}{l}\text { USA: New } \\
\text { Hampshire, } \\
\text { Vermont. }\end{array}$ & $\begin{array}{l}\text { (i) } 223 \text { lung } \\
\text { cancer ( } 100 \\
\text { male/ } 123 \text { female) } \\
\text { (ii) } 238 \text { controls }\end{array}$ & $\begin{array}{l}75 \text { cases were SqCC } \\
\text { and SCC }\end{array}$ & $\begin{array}{l}\text { Data from cases } \\
\text { (i) } 5.4 \% \text { never } \\
\text { smokers } \\
\text { (ii) } 94.6 \% \text { current }\end{array}$ & $\begin{array}{l}\text { Arsenic exposure was associated } \\
\text { with SCC and SqCC }(\mathrm{OR}=2.75 \\
\text { for toenail arsenic concentration } \\
\geq 0.114 \mu \mathrm{g} / \mathrm{g} \text { versus }<0.05 \mu \mathrm{g} / \mathrm{g})\end{array}$ & $\begin{array}{l}\text { Toe nail (arsenic) } \\
\text { in } 4 \text { levels: } \\
<0.05 \mu \mathrm{g} / \mathrm{g}, 0.05 \\
\text { to }<0.0768 \mu \mathrm{g} / \mathrm{g} \text {, } \\
0.768 \\
\text { to }<0.1137 \mu \mathrm{g} / \mathrm{g}, \\
\text { and } \geq 0.1137 \mu \mathrm{g} / \mathrm{g}\end{array}$ & [99] \\
\hline
\end{tabular}

${ }^{\dagger}$ Data from patients from the Blackfoot Disease area in Taiwan.

SCC: small cell carcinoma; NA: data not available; SMR: standardized mortality rate; OR: odds ratios.

to its accumulation in epithelial tissues leading to further DNA-protein cross-links, DNA damage, and possibly other defects. Indeed, keratin synthesis is tightly correlated with differentiation programs of a range of epithelial cell types [78]. Therefore, arsenic could not only damage DNA but also modify differentiation patterns in the cells where it accumulates. The subsequent arsenic-induced genetic and epigenetic alterations could finally lead to the development of SqCC.

\subsection{Genetic and Epigenetic Alterations Associated with Arsenic} Exposure. Some genetic alterations have been described to be specifically associated to arsenic ingestion in humans. For example, Moore et al. identified genomic changes in bladder tumors (transitional cell carcinoma, TCC) from arsenic-exposed patients using chromosomal comparative genomic hybridization (CGH) [79]. Among different recurrent arsenic-related DNA copy number alterations (CNAs) identified, DNA loss of chromosome 9q is remarkable, since it was the only alteration more frequently observed in never smokers than in ever smokers in this study. Similarly, Hsu et al. identified CNAs on bladder TCC tumors from southwest Taiwan [80]. Gain at $3 \mathrm{p}$ and loss at $17 \mathrm{p} 13$ were consistent with findings from northern Chile and Argentina.

Recently, arsenic-related CNAs were identified among lung SqCCs from chronically exposed patients from northern Chile [81]. Alterations were identified by a whole genome tiling-path array comparative genomic hybridization (CGH) platform (described in $[82,83]$ ). Noticeably, a 0.3 Mb DNA loss at 9q12 was preferentially detected among arsenicexposed cases (Figure 2). The role of chromosome $9 \mathrm{q}$ on arsenic-induced human tumors needs to be further investigated; however, common alterations detected among bladder and lung tumors indicate a potential participation on arsenic-related neoplastic process.

Arsenic also has epigenetic effects at the level of DNA methylation, histone maintenance, and miRNA expression (reviewed in [36, 37, 84]). Since arsenic biotransformation uses S-adenosylmethionine (SAM) as a methyl group donor, it has been proposed that SAM depletion can interfere with cellular processes that require methyl groups, leading to the idea that alteration of epigenetic mechanisms can also participate in arsenic-induced carcinogenesis [35]. Promoter hypermethylation affecting P53, p16INK4A, RASSF1A, and PRSS3 has been described in lung cancer cell lines and tumor tissues from mice and human [85-87]. On the other hand, arsenic can modify normal histone patterns. As [III] has also been shown to increase H3K9 dimethylation and decrease H3K27 trimethylation, marks associated with heterochromatin formation (i.e., gene silencing) and a decrease in $\mathrm{H} 3 \mathrm{~K} 4$ trimethylation which is associated with actively transcribed euchromatin [88]. In human nontumorogenic cell lines, arsenic-induced malignant transformation provoked changes in expression for specific genes, which was correlated with the histone acetylation levels for their respective promoter regions [89].

In the few past years, miRNAs have been intensively studied in the context of arsenic-related cancer. An increasing number of studies show that arsenic exposure can alter miRNA expression levels in vitro and in vivo. miRNA alterations associated with arsenic (or its metabolites) have been demonstrated in human lymphoblastoid cells, human peripheral blood-derived cells, and chick embryos [87, 90]. Exposure of immortalized human bronchial epithelial cells to low levels of arsenic induced malignant transformation and epithelial-to-mesenchymal transition in p53- dependent manner by reducing levels of miR-200 family members [91]. In the case of human peripheral blood-derived cells, changes in miRNA could be related with changes in methylation patterns, since the same alterations were observed when cells were grown under folate-deficient conditions, which can lead to reduced levels of SAM [87].

\section{Conclusion}

Arsenic in drinking water affects millions of people worldwide, posing an urgent health concern [92]. Hundreds of 


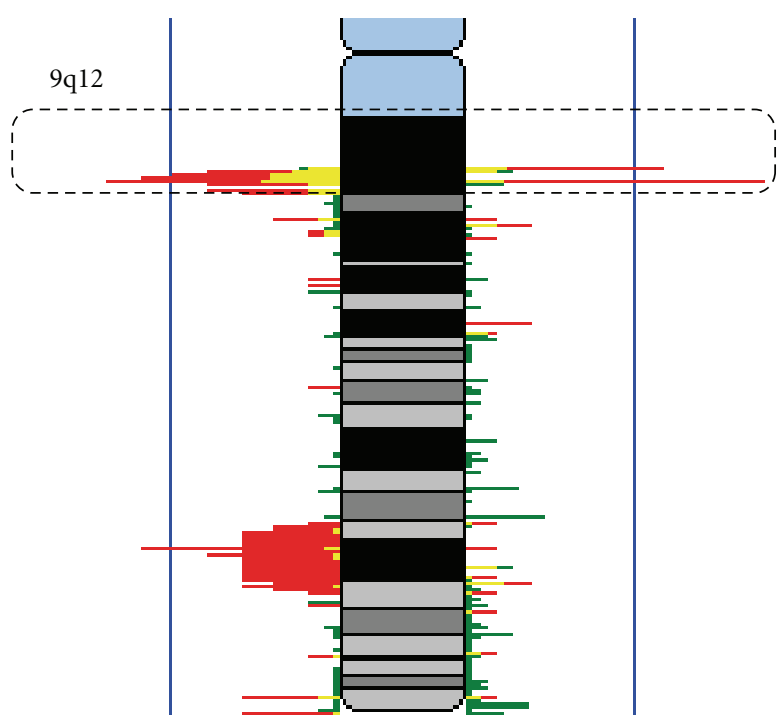

Figure 2: DNA copy-number alteration at chromosome $9 \mathrm{q}$ in arsenic-exposed lung SqCC. CNA frequencies are overlaid in this karyogram. Profiles of 52 lung SqCC biopsies were generated using a submegabase resolution tiling-set rearray (SMRTr) platform. Twenty-two arsenic-exposed samples (shown in red) were obtained from lung cancer patients from northern Chile. Thirty samples from patients without known arsenic exposure (green) were obtained from North American individuals. Regions in yellow denote a sector of overlapping alteration status in both groups. The magnitude of red, green, and yellow bars represents percentage of samples $(0-100 \%$, with blue vertical lines representing $50 \%$ frequency) exhibiting DNA gains (to the right) and DNA losses (to the left). Dotted line represents $9 \mathrm{q} 12$ cytoband.

millions of people have been exposed to this metalloid through drinking water, resulting in morbidity and mortality globally $[5,6]$. Arsenic causes a variety of health problems, significantly cancer, whose symptoms may not appear for 20 to 30 years after exposure [93].

Several genomic aberrations have been described for arsenic-induced cancers. Based on distinctive profiles of genomic changes, it has been proposed that arsenic-induced lung SqCC could correspond to a molecularly distinct form of lung cancer [81]. Additionally, the arsenic biotransformation process is associated with a series of methylation changes, which has led to the hypothesis that epigenetic changes play a key role in arsenic-induced carcinogenesis. Changes in DNA methylation patterns (especially at promoter regions of key genes) and alterations to the "histone code" are likely mechanisms of arsenic-induced malignant transformation. Additionally, miRNAs seem to play an important role at this level.

Understanding the mechanisms underlying the preferential occurrence of squamous cell-type tumors associated with arsenic exposure, especially skin and lung cancer, is an urgent health care issue. Arsenic has been shown to promote a dramatic increase in expression of keratins related to squamous differentiation, which can be, in part, a consequence of genetic and epigenetic changes associated with arsenic biotransformation. This corresponds to a potential mechanism for explaining the preferential histological subtype induced by arsenic, independent of the target organ. Further research is needed in order to clarify the molecular mechanisms governing arsenic-driven carcinogenesis, as well as preference for histological subtypes. This knowledge can improve strategies oriented to early diagnosis or targeted therapies of these and other arsenic-related diseases.

\section{Acknowledgments}

This work was supported by funds from the Canadian Institutes for Health Research (MOP 86731 and MOP 77903), Canadian Cancer Society (CCS20485), and a CIHR Frederick Banting and Charles Best Canada Graduate Scholarship to E. A. Vucic.

\section{References}

[1] International Agency for Research on Cancer (IARC), "Some drinking-water disinfectants and contaminants, including arsenic. Monographs on chloramine, chloral and chloral hydrate, dichloroacetic acid, trichloroacetic acid and 3-chloro-4(dichloromethyl)-5-hydroxy-2(5H)-furanone," IARC Monographs on the Evaluation of Carcinogenic Risks to Humans, vol. 84, pp. 269-477, 2004.

[2] World Health Organization (WHO), WHO Guidelines for Drinking-Water Quality, 1993.

[3] U.S. Environmental Protection Agency (EPA), "National Primary Drinking Water Reguations. Arsenic and Clarifications to Compilance and New Source Contaminants Monitoring, in Final rule. Delay of effective date," Federal Registry, pp. 1613416135, 2001.

[4] P. L. Smedley and D. G. Kinniburgh, "A review of the source, behaviour and distribution of arsenic in natural waters," Applied Geochemistry, vol. 17, no. 5, pp. 517-568, 2002.

[5] M. Argos, T. Kalra, B. L. Pierce et al., "A prospective study of arsenic exposure from drinking water and incidence of skin lesions in Bangladesh," American Journal of Epidemiology, vol. 174, no. 2, pp. 185-194, 2011.

[6] World Health Organization (WHO), Water Sanitation and Health, World Health Organization, Geneva, Switzerland, 2004.

[7] D. Chakraborti, M. M. Rahman, K. Paul et al., "Arsenic calamity in the Indian subcontinent: what lessons have been learned?" Talanta, vol. 58, no. 1, pp. 3-22, 2002.

[8] X. Guo, Y. Fujino, J. Chai et al., "The prevalence of subjective symptoms after exposure to arsenic in drinking water in Inner Mongolia, China," Journal of Epidemiology, vol. 13, no. 4, pp. 211-215, 2003.

[9] C. J. Chen, Y. C. Chuang, T. M. Lin, and H. Y. Wu, "Malignant neoplasms among residents of a blackfoot disease-endemic area in Taiwan: high-arsenic artesian well water and cancers," Cancer Research, vol. 45, no. 11, pp. 5895-5899, 1985.

[10] M. Vahter, "Mechanisms of arsenic biotransformation," Toxicology, vol. 181-182, pp. 211-217, 2002.

[11] Agency for Toxic Substances and Disease Registry (ATSDR), Toxicological Profile for Arsenic, P.H.S. U.S. Department of Health and Human Services, 2007.

[12] D. N. G. Mazumder, "Diagnosis and treatment of chronic arsenic poisoning," in United Nations Synthesis Report on Arsenic in Drinking Water, 2000. 
[13] W. P. Tseng, "Effects and dose response relationships of skin cancer and blackfoot disease with arsenic," Environmental Health Perspectives, vol. 19, pp. 109-119, 1977.

[14] C. J. Chen, Y. M. Hsueh, M. S. Lai et al., "Increased prevalence of hypertension and long-term arsenic exposure," Hypertension, vol. 25, no. 1, pp. 53-60, 1995.

[15] R. R. Engel, C. Hopenhayn-Rich, O. Receveur, and A. H. Smith, "Vascular effects of chronic arsenic exposure: a review," Epidemiologic Reviews, vol. 16, no. 2, pp. 184-209, 1994.

[16] T. Kadono, T. Inaoka, N. Murayama et al., "Skin manifestations of arsenicosis in two villages in Bangladesh," International Journal of Dermatology, vol. 41, no. 12, pp. 841846, 2002.

[17] J. Pi, Y. Kumagai, G. Sun et al., "Decreased serum concentrations of nitric oxide metabolites among Chinese in an endemic area of chronic arsenic poisoning in inner Mongolia," Free Radical Biology and Medicine, vol. 28, no. 7, pp. 1137-1142, 2000.

[18] Sai Siong Wong, Kong Chong Tan, and Chee Leok Goh, "Cutaneous manifestations of chronic arsenicism: review of seventeen cases," Journal of the American Academy of Dermatology, vol. 38, no. 2 I, pp. 179-185, 1998.

[19] G. Alain, J. Tousignant, and E. Rozenfarb, "Chronic arsenic toxicity," International Journal of Dermatology, vol. 32, no. 12, pp. 899-991, 1993.

[20] C. J. Chen and C. J. Wang, "Ecological correlation between arsenic level in well water and age-adjusted mortality from malignant neoplasms," Cancer Research, vol. 50, no. 17, pp. 5470-5474, 1990.

[21] A. H. Smith, M. Goycolea, R. Haque, and M. L. Biggs, "Marked increase in bladder and lung cancer mortality in a region of northern chile due to arsenic in drinking water," American Journal of Epidemiology, vol. 147, no. 7, pp. 660-669, 1998.

[22] C. Hopenhayn-Rich, M. L. Biggs, A. Fuchs et al., "Bladder cancer mortality associated with arsenic in drinking water in Argentina," Epidemiology, vol. 7, no. 2, pp. 117-124, 1996.

[23] K. H. Morales, L. Ryan, T. L. Kuo, M. M. Wu, and C. J. Chen, "Risk of internal cancers from arsenic in drinking water," Environmental Health Perspectives, vol. 108, no. 7, pp. 655-661, 2000.

[24] C. Ferreccio, C. González, V. Milosavjlevic, G. Marshall, A. M. Sancha, and A. H. Smith, "Lung cancer and arsenic concentrations in drinking water in Chile," Epidemiology, vol. 11, no. 6, pp. 673-679, 2000.

[25] G. Marshall, C. Ferreccio, Y. Yuan et al., "Fifty-Year study of lung and bladder cancer mortality in Chile related to arsenic in drinking water," Journal of the National Cancer Institute, vol. 99, no. 12, pp. 920-928, 2007.

[26] A. H. Smith, C. Hopenhayn-Rich, M. N. Bates et al., "Cancer risks from arsenic in drinking water," Environmental Health Perspectives, vol. 97, pp. 259-267, 1992.

[27] M. N. Mead, "Arsenic: in search of an antidote to a global poison," Environmental Health Perspectives, vol. 113, no. 6, pp. A378-A386, 2005.

[28] M. M. Wu, T. L. Kuo, Y. H. Hwang, and C. J. Chen, "Doseresponse relation between arsenic concentration in well water and mortality from cancers and vascular diseases," American Journal of Epidemiology, vol. 130, no. 6, pp. 1123-1132, 1989.

[29] C. J. Chen, T. L. Kuo, and M. M. Wu, "Arsenic and cancers," The Lancet, vol. 1, no. 8582, pp. 414-415, 1988.

[30] C. J. Chen, C. W. Chen, M. M. Wu, and T. L. Kuo, "Cancer potential in liver, lung, bladder and kidney due to ingested inorganic arsenic in drinking water," British Journal of Cancer, vol. 66, no. 5, pp. 888-892, 1992.
[31] M. N. Bates, A. H. Smith, and C. Hopenhayn-Rich, "Arsenic ingestion and internal cancers: a review," American Journal of Epidemiology, vol. 135, no. 5, pp. 462-476, 1992.

[32] W. R. Cullen, B. C. McBride, and J. Reglinski, "The reaction of methylarsenicals with thiols: some biological implications," Journal of Inorganic Biochemistry, vol. 21, no. 3, pp. 179-193, 1984.

[33] M. Styblo et al., "The role of biomethyl-ation in toxicity and carcinogenicity of arsenic: a research update," Environmental Health Perspectives, vol. 110, p. 767, 2002.

[34] D. J. Thomas, M. Styblo, and S. Lin, "The cellular metabolism and systemic toxicity of arsenic," Toxicology and Applied Pharmacology, vol. 176, no. 2, pp. 127-144, 2001.

[35] P. P. Simeonova and M. I. Luster, "Mechanisms of arsenic carcinogenicity: genetic or epigenetic mechanisms?" Journal of Environmental Pathology, Toxicology and Oncology, vol. 19, no. 3, pp. 281-286, 2000.

[36] X. Ren, C. M. Mchale, C. F. Skibola, A. H. Smith, M. T. Smith, and L. Zhang, "An emerging role for epigenetic dysregulation in arsenic toxicity and carcinogenesis," Environmental Health Perspectives, vol. 119, no. 1, pp. 11-19, 2011.

[37] J. F. Reichard and A. Puga, "Effects of arsenic exposure on DNA methylation and epigenetic gene regulation," Epigenomics, vol. 2, no. 1, pp. 87-104, 2010.

[38] International Agency for Research on Cancer (IARC), "Some drinking-water disinfectants and contaminants, including arsenic," in IARC Monographs on the Evaluation of Carcinogenic Risks to Humans, pp. 39-267, World Health Organization, Lyon, France, 2004.

[39] National Research Council (NRC), Arsenic in Drinking Water: 2001 Update, National Academy Press, Washington, DC, USA, 2001.

[40] H. R. Guo, N. S. Wang, H. Hu, and R. R. Monson, "Cell type specificity of lung cancer associated with arsenic ingestion," Cancer Epidemiology Biomarkers and Prevention, vol. 13, no. 4, pp. 638-643, 2004.

[41] P. Ramírez, L. M. Del Razo, M. C. Gutierrez-Ruíz, and M. E. Gonsebatt, "Arsenite induces DNA-protein crosslinks and cytokeratin expression in the WRL-68 human hepatic cell line," Carcinogenesis, vol. 21, no. 4, pp. 701-706, 2000.

[42] H. R. Guo, H. S. Yu, H. Hu, and R. R. Monson, "Arsenic in drinking water and skin cancers: cell-type specificity (Taiwan, R.O.C.)," Cancer Causes and Control, vol. 12, no. 10, pp. 909916, 2001.

[43] J. A. Centeno, F. G. Mullick, L. Martinez et al., "Pathology related to chronic arsenic exposure," Environmental Health Perspectives, vol. 110, no. 5, pp. 883-886, 2002.

[44] H. S. Yu, C. H. Lee, S. H. Jee, C. K. Ho, and Y. L. Guo, "Environmental and occupational skin diseases in Taiwan," Journal of Dermatology, vol. 28, no. 11, pp. 628-631, 2001.

[45] W. P. Tseng, H. M. Chu, S. W. How, J. M. Fong, C. S. Lin, and S. Yeh, "Prevalence of skin cancer in an endemic area of chronic arsenicism in Taiwan," Journal of the National Cancer Institute, vol. 40, no. 3, pp. 453-463, 1968.

[46] S. Yeh, S. W. How, and C. S. Lin, "Arsenical cancer of skin. Histologic study with special reference to Bowen's disease," Cancer, vol. 21, no. 2, pp. 312-339, 1968.

[47] K. Castrén, A. Ranki, J. A. Welsh, and K. H. Vähäkangas, "Infrequent p53 mutations in arsenic-related skin lesions," Oncology Research, vol. 10, no. 9, pp. 475-482, 1998.

[48] H. S. Yu, W. T. Liao, and C. Y. Chai, "Arsenic carcinogenesis in the skin," Journal of Biomedical Science, vol. 13, no. 5, pp. 657-666, 2006. 
[49] S. Ouypornkochagorn and J. Feldmann, "Dermal uptake of arsenic through human skin depends strongly on its speciation," Environmental Science and Technology, vol. 44, no. 10, pp. 3972-3978, 2010.

[50] L. Bernstam, C. H. Lan, J. Lee, and J. O. Nriagu, "Effects of arsenic on human keratinocytes: morphological, physiological, and precursor incorporation studies," Environmental Research, vol. 89, no. 3, pp. 220-235, 2002.

[51] T. J. Patterson and R. H. Rice, "Arsenite and insulin exhibit opposing effects on epidermal growth factor receptor and keratinocyte proliferative potential," Toxicology and Applied Pharmacology, vol. 221, no. 1, pp. 119-128, 2007.

[52] T. J. Patterson, T. V. Reznikova, M. A. Phillips, and R. H. Rice, "Arsenite maintains germinative state in cultured human epidermal cells," Toxicology and Applied Pharmacology, vol. 207, no. 1, pp. 69-77, 2005.

[53] R. J. Morris and C. S. Potten, "Slowly cycling (label-retaining) epidermal cells behave like clonogenic stem cells in vitro," Cell Proliferation, vol. 27, no. 5, pp. 279-289, 1994.

[54] G. Cotsarelis, T. T. Sun, and R. M. Lavker, "Label-retaining cells reside in the bulge area of pilosebaceous unit: implications for follicular stem cells, hair cycle, and skin carcinogenesis," Cell, vol. 61, no. 7, pp. 1329-1337, 1990.

[55] S. J. Wei, C. S. Trempus, R. E. Cannon, C. D. Bortner, and R. W. Tennant, "Identification of Dss1 as a 12-Otetradecanoylphorbol-13-acetate-responsive gene expressed in keratinocyte progenitor cells, with possible involvement in early skin tumorigenesis," Journal of Biological Chemistry, vol. 278, no. 3, pp. 1758-1768, 2003.

[56] M. P. Waalkes, J. Liu, D. R. Germolec et al., "Arsenic exposure in utero exacerbates skin cancer response in adulthood with contemporaneous distortion of tumor stem cell dynamics," Cancer Research, vol. 68, no. 20, pp. 8278-8285, 2008.

[57] H. Dang, C. Trempus, D. E. Malarkey et al., "Identification of genes and gene ontology processes critical to skin papilloma development in Tg.AC transgenic mice," Molecular Carcinogenesis, vol. 45, no. 2, pp. 126-140, 2006.

[58] J. Pi, B. A. Diwan, Y. Sun et al., "Arsenic-induced malignant transformation of human keratinocytes: involvement of Nrf2," Free Radical Biology and Medicine, vol. 45, no. 5, pp. 651-658, 2008.

[59] B. E. Bachmeier, P. Boukamp, R. Lichtinghagen, N. E. Fusenig, and E. Fink, "Matrix metalloproteinases-2,-3,-7,-9 and -10, but not MMP-11, are differentially expressed in normal, benign tumorigenic and malignant human keratinocyte cell lines," Biological Chemistry, vol. 381, no. 5-6, pp. 497-507, 2000.

[60] E. J. Bernhard, S. B. Gruber, and R. J. Muschel, "Direct evidence linking expression of matrix metalloproteinase 9 (92$\mathrm{kDa}$ gelatinase/collagenase) to the metastatic phenotype in transformed rat embryo cells," Proceedings of the National Academy of Sciences of the United States of America, vol. 91, no. 10, pp. 4293-4297, 1994.

[61] T. G. Rossman, A. N. Uddin, and F. J. Burns, "Evidence that arsenite acts as a cocarcinogen in skin cancer," Toxicology and Applied Pharmacology, vol. 198, no. 3, pp. 394-404, 2004.

[62] Servicio de Salud Antofagasta (Unidad de Registro de Cancer), III Anuario Registro Regional de Cancer Segunda Region Chile 2000 (Incluye informacion 1998-2000), Ministerio de salud, Antofagasta, Chile, 2000.

[63] M. G. Mostafa, J. C. McDonald, and N. Cherry, "Lung cancer and exposure to arsenic in rural Bangladesh," Occupational and Environmental Medicine, vol. 65, no. 11, pp. 765-768, 2008.
[64] H. Luchtrath, "The consequences of chronic arsenic poisoning among moselle wine growers. Pathoanatomical investigations of post-mortem examination performed between 1960 and 1977," Journal of Cancer Research and Clinical Oncology, vol. 105, no. 2, pp. 173-182, 1983.

[65] G. Pershagen, F. Bergman, and J. Klominek, "Histological types of lung cancer among smelter workers exposed to arsenic," British Journal of Industrial Medicine, vol. 44, no. 7, pp. 454-458, 1987.

[66] O. Axelson, E. Dahlgren, C. D. Jansson, and S. O. Rehnlund, "Arsenic exposure and mortality: a case-referent study from a Swedish copper smelter," British Journal of Industrial Medicine, vol. 35 , no. 1, pp. 8-15, 1978.

[67] M. J. Wicks, V. E. Archer, O. Auerbach, and M. Kuschner, "Arsenic exposure in a copper smelter as related to histological type of lung cancer," American Journal of Industrial Medicine, vol. 2, no. 1, pp. 25-31, 1981.

[68] D. Taeger, G. Johnen, T. Wiethege et al., "Major histopathological patterns of lung cancer related to arsenic exposure in German uranium miners," International Archives of Occupational and Environmental Health, vol. 82, no. 7, pp. 867-875, 2009.

[69] E. B. L. Van Dorst, G. N. P. Van Muijen, S. V. Litvinov, and G. J. Fleuren, "The limited difference between keratin patterns of squamous cell carcinomas and adenocarcinomas is explicable by both cell lineage and state of differentiation of tumour cells," Journal of Clinical Pathology, vol. 51, no. 9, pp. 679-684, 1998.

[70] M. Osborn and K. Weber, "Intermediate filaments: cell-typespecific markers in differentiation and pathology," Cell, vol. 31, no. 2, pp. 303-306, 1982.

[71] L. Cao, X. D. Zhou, M. A. Sens et al., "Keratin 6 expression correlates to areas of squamous differentiation in multiple independent isolates of As+3-induced bladder cancer," Journal of Applied Toxicology, vol. 30, no. 5, pp. 416-430, 2010.

[72] Y. Sun, J. Pi, X. Wang, E. J. Tokar, J. Liu, and M. P. Waalkes, "Aberrant cytokeratin expression during arsenicinduced acquired malignant phenotype in human $\mathrm{HaCaT}$ keratinocytes consistent with epidermal carcinogenesis," Toxicology, vol. 262, no. 2, pp. 162-170, 2009.

[73] H. S. Yu, K. S. Chiou, G. S. Chen, R. C. Yang, and S. F. Chang, "Progressive alterations of cytokeratin expressions in the process of chronic arsenism," Journal of Dermatology, vol. 20, no. 12, pp. 741-745, 1993.

[74] R. L. Eckert, J. F. Crish, and N. A. Robinson, "The epidermal keratinocyte as a model for the study of gene regulation and cell differentiation," Physiological Reviews, vol. 77, no. 2, pp. 397-424, 1997.

[75] M. J. Gerdes and S. H. Yuspa, "The contribution of epidermal stem cells to skin cancer," Stem Cell Reviews, vol. 1, no. 3, pp. 225-232, 2005.

[76] Y. Liu, S. Lyle, Z. Yang, and G. Cotsarelis, "Keratin 15 promoter targets putative epithelial stem cells in the hair follicle bulge," Journal of Investigative Dermatology, vol. 121, no. 5, pp. 963968, 2003.

[77] S. Lyle, M. Christofidou-Solomidou, Y. Liu, D. E. Elder, S. Albelda, and G. Cotsarelis, "The C8/144B monoclonal antibody recognizes cytokeratin 15 and defines the location of human hair follicle stem cells," Journal of Cell Science, vol. 111, no. 21, pp. 3179-3188, 1998.

[78] E. Fuchs, "The cytoskeleton and disease: genetic disorders of intermediate filaments," Annual Review of Genetics, vol. 30, pp. 197-231, 1996. 
[79] L. E. Moore, A. H. Smith, C. Eng et al., "Arsenic-related chromosomal alterations in bladder cancer," Journal of the National Cancer Institute, vol. 94, no. 22, pp. 1688-1696, 2002.

[80] L. I. Hsu, A. W. Chiu, Y. S. Pu et al., "Comparative genomic hybridization study of arsenic-exposed and non-arsenicexposed urinary transitional cell carcinoma," Toxicology and Applied Pharmacology, vol. 227, no. 2, pp. 229-238, 2008.

[81] V. D. Martinez, T. P. H. Buys, M. Adonis et al., "Arsenicrelated DNA copy-number alterations in lung squamous cell carcinomas," British Journal of Cancer, vol. 103, no. 8, pp. 1277-1283, 2010.

[82] A. S. Ishkanian, C. A. Malloff, S. K. Watson et al., "A tiling resolution DNA microarray with complete coverage of the human genome," Nature Genetics, vol. 36, no. 3, pp. 299-303, 2004.

[83] S. K. Watson, R. J. deLeeuw, D. E. Horsman, J. A. Squire, and W. L. Lam, "Cytogenetically balanced translocations are associated with focal copy number alterations," Human Genetics, vol. 120, no. 6, pp. 795-805, 2007.

[84] V. Martinez, "Arsenic biotransformation as a cancer promoting factor by inducing DNA damage and disruption of repair mechanisms," Molecular Biology International, vol. 2011, Article ID 718974, 11 pages, 2011.

[85] M. J. Mass and L. Wang, "Arsenic alters cytosine methylation patterns of the promoter of the tumor suppressor gene p53 in human lung cells: a model for a mechanism of carcinogenesis," Mutation Research, vol. 386, no. 3, pp. 263-277, 1997.

[86] X. Cui, T. Wakai, Y. Shirai, K. Hatakeyama, and S. Hirano, "Chronic oral exposure to inorganic arsenate interferes with methylation status of p16INK4a and RASSF1A and induces lung cancer in A/J mice," Toxicological Sciences, vol. 91, no. 2, pp. 372-381, 2006.

[87] C. J. Marsit, K. Eddy, and K. T. Kelsey, "MicroRNA responses to cellular stress," Cancer Research, vol. 66, no. 22, pp. 10843 10848, 2006.

[88] X. Zhou, H. Sun, T. P. Ellen, H. Chen, and M. Costa, "Arsenite alters global histone H3 methylation," Carcinogenesis, vol. 29, no. 9, pp. 1831-1836, 2008.

[89] T. J. Jensen, P. Novak, K. E. Eblin, J. A. Gandolfi, and B. W. Futscher, "Epigenetic remodeling during arsenical-induced malignant transformation," Carcinogenesis, vol. 29, no. 8, pp. 1500-1508, 2008.

[90] Y. Cui et al., "MicroRNA-181b and microRNA-9 mediate arsenic-induced angiogenesis via NRP1," Journal of Cellular Physiology, vol. 227, no. 2, pp. 772-783, 2012.

[91] Z. Wang, Y. Zhao, E. Smith et al., "Reversal and prevention of arsenic-induced human bronchial epithelial cell malignant transformation by microRNA-200b," Toxicological Sciences, vol. 121, no. 1, pp. 110-122, 2011.

[92] D. K. Nordstrom, "Worldwide occurrences of arsenic in ground water," Science, vol. 296, no. 5576, pp. 2143-2145, 2002.

[93] C. Ferreccio and A. M. Sancha, "Arsenic exposure and its impact on health in Chile," Journal of Health, Population and Nutrition, vol. 24, no. 2, pp. 164-175, 2006.

[94] A. O. Robson and A. M. Jelliffe, "Medicinal arsenic poisoning and lung cancer," British Medical Journal, vol. 2, no. 5351, pp. 207-209, 1963.

[95] C. J. Chen, Y. C. Chuang, and S. L. You, "A retrospective study on malignant neoplasms of bladder, lung and liver in blackfoot disease endemic area in Taiwan," British Journal of Cancer, vol. 53, no. 3, pp. 399-405, 1986.

[96] T. Tsuda, A. Babazono, E. Yamamoto et al., "Ingested arsenic and internal cancer: a historical cohort study followed for 33 years," American Journal of Epidemiology, vol. 141, no. 3, pp. 198-209, 1995.

[97] C. L. Chen, L. I. Hsu, H. Y. Chiou et al., "Ingested arsenic, cigarette smoking, and lung cancer risk: a follow-up study in arseniasis-endemic areas in Taiwan," Journal of the American Medical Association, vol. 292, no. 24, pp. 2984-2990, 2004.

[98] C. L. Chen, H. Y. Chiou, L. I. Hsu, Y. M. Hsueh, M. M. Wu, and C. J. Chen Chien-Jen, "Ingested arsenic, characteristics of well water consumption and risk of different histological types of lung cancer in northeastern Taiwan," Environmental Research, vol. 110, no. 5, pp. 455-462, 2010.

[99] J. E. Heck, A. S. Andrew, T. Onega et al., "Lung cancer in a U.S. population with low to moderate arsenic exposure," Environmental Health Perspectives, vol. 117, no. 11, pp. 17181723, 2009. 


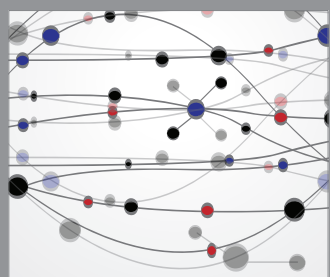

The Scientific World Journal
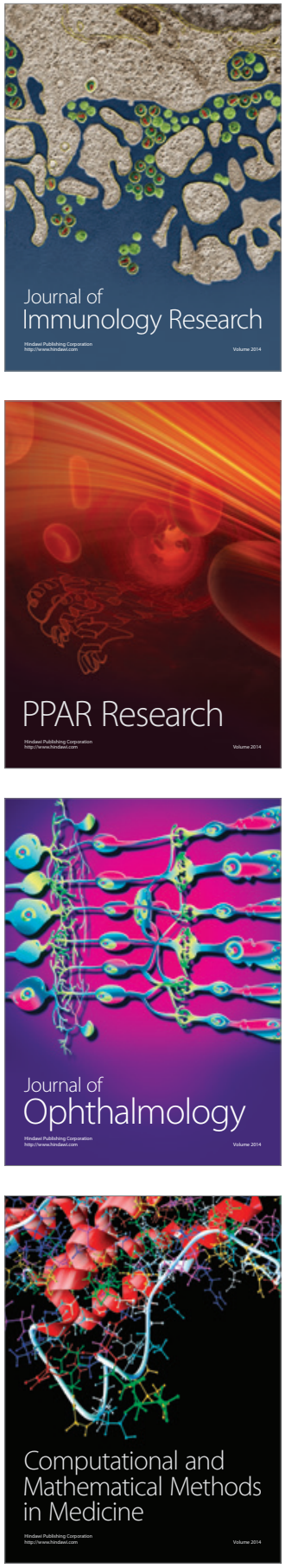

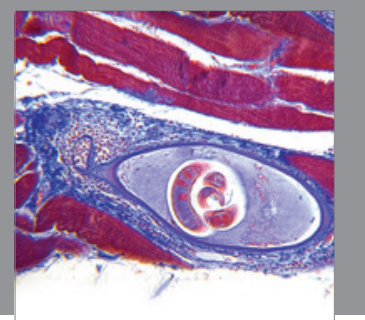

Gastroenterology

Research and Practice
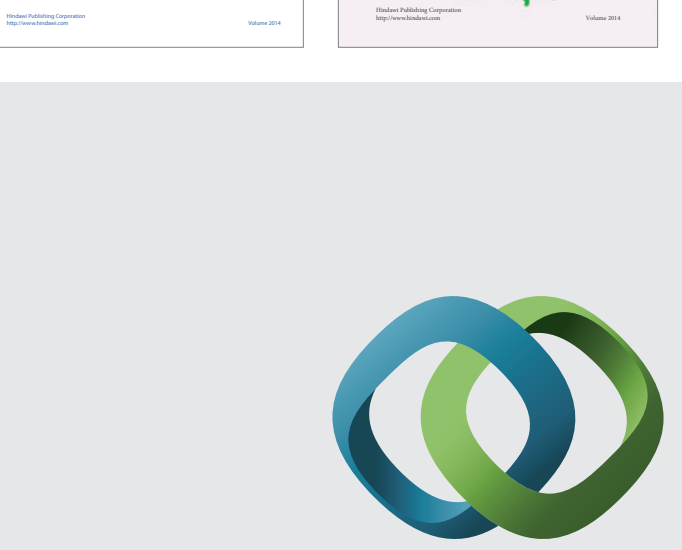

\section{Hindawi}

Submit your manuscripts at

http://www.hindawi.com
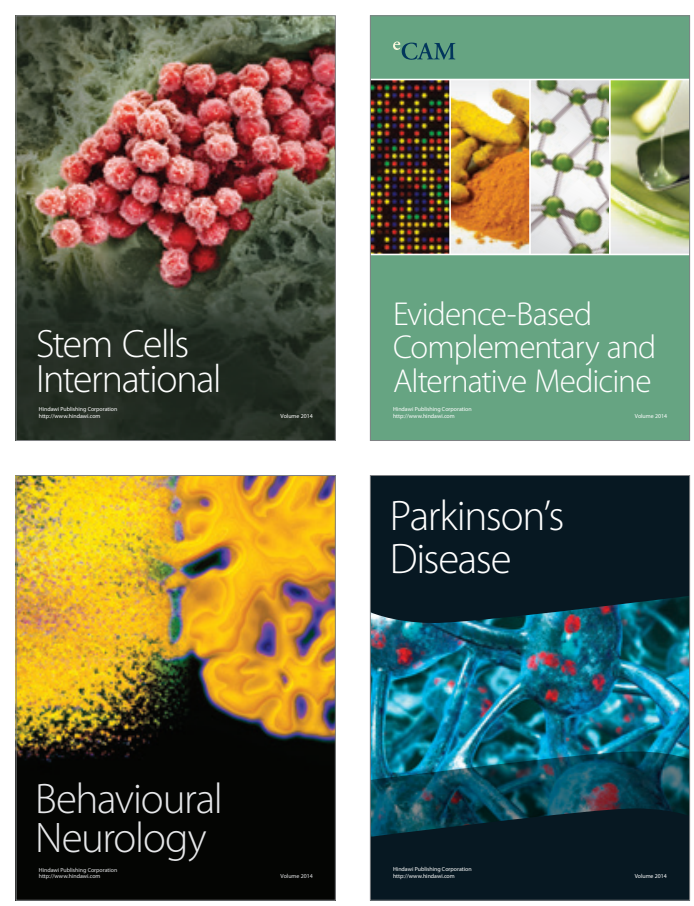

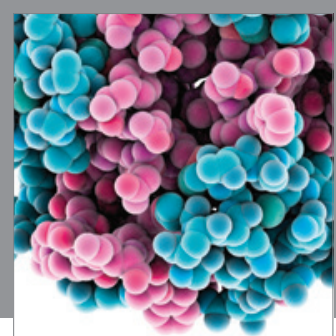

Journal of
Diabetes Research

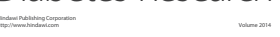

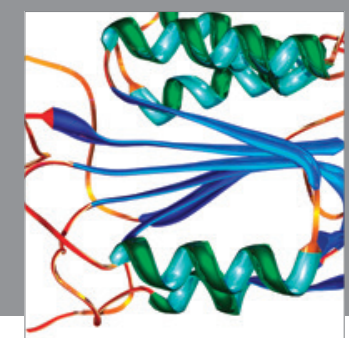

Disease Markers
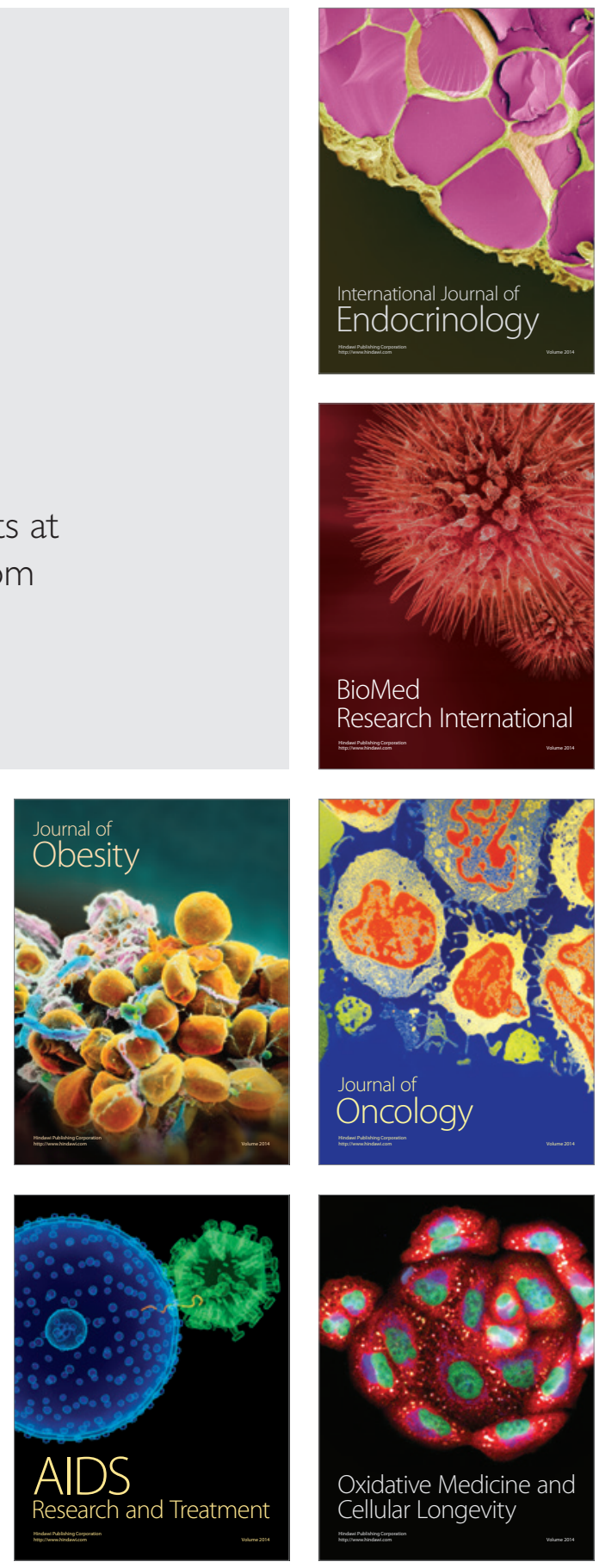